\title{
Microbiological analysis of ready to eat foods collected from different places of Dhaka city, Bangladesh
}

\author{
Md. Aftab Uddin* \\ Department of Microbiology, Stamford University Bangladesh, 51 Siddeswari Road, Dhaka 1217, Bangladesh
}

Received 17 August 2018/Accepted 21 September 2018

\begin{abstract}
The current study was attempted to observe the microbiological quality of ready to eat foods collected from different places of Dhaka city, Bangladesh. Ten food samples that include five fried items-fried chicken, fish fillet, shrimp fries, French fries, potato chop and five sweet items-yoghurt, pudding, ice cream, mango drink, lemon drink were analyzed during the period from September 2017 to November 2017. Conventional cultural, microscopic and biochemical tests were followed for the detection and enumeration of bacterial isolates associated with these food samples. The investigation encompassed detection of total viable bacterial count $(\mathrm{TVBC})$ and presumptive identification of other pathogenic bacteria from these samples. The higher counts of TVBC, Escherichia coli, Staphylococcus aureus and Bacillus spp. were recorded as $1.94 \times 10^{6} \mathrm{cfu} / \mathrm{g}$ (potato chop), $3.1 \times 10^{4} \mathrm{cfu} / \mathrm{g}$ (fried shrimp), $7.5 \times 10^{3} \mathrm{cfu} / \mathrm{g}$ (fried chicken) and $1.0 \times 10^{3} \mathrm{cfu} / \mathrm{g}$ (French fries) respectively. Based on the specifications by International Commission for Microbiological Specification for Foods (ICMSF), the level of contaminations was within acceptable microbiological limits except for potato chop.
\end{abstract}

Key words: Ready-to-eat foods, Microbiological analysis; Food safety

Ready-to-eat (RTE) foods have become more and more accepted in the last few years, specifically in metropolitan areas (1). Ready-to-eat (RTE) foods implies those foods that do not need further significant processing other than reheating or completion of a cooking process $(2,3)$. It has been found that RTE takeaway foods is dealing with a large volume of sales of the food service sector, representing more than a third of the food service volume outputs (4). Well known taste, cheap in price and convenience are some of the attracting factors that make RTE foods popular as food source. The RTE food products offer a source of readily available and wholesome meals for the consumer (5).

Food borne disease outbreaks linked with RTE foods have been linked with different types of foodborne pathogens $(6,7)$. The occurrence of foodborne illness is escalating worldwide $(8,9)$. The original microbiological load on RTE food ingredients is vital, however, factors such as handling, processing, storage and display may persuade the microbiological load of RTE foods at the point of sale (10). Ready to eat foods are often processed by hand and this direct contact may lead to an augmented incidence of contamination with potential food borne pathogens, such as Staphylococcus spp (11). The microbiology of RTE foods during preparation in factories, in domestic

*Corresponding Author: Mailing address. Md. Aftab Uddin, Assistant Professor, Department of Microbiology, Stamford University Bangladesh, 51 Siddeswari Road, Dhaka 1217, Bangladesh, Bangladesh; E-mail: aftab_mb12@yahoo.com. kitchens, in canteens and on street corners by street vendors has formerly been examined (12).

Elevated counts of Escherichia coli and total coliform (TC) in foods usually implies lack of hygiene in handling and production operations, insufficient storage and postprocess contamination (13). Therefore, E. coli and TC enumeration are used as a food-quality stricture. Bacillus cereus is commonly isolated from the natural environment (soil and growing plants) and foods, meat products, raw meat and meat product additives. Salmonella can repeatedly be isolated from raw foods of animal origin. Environmental contamination can also effect in Salmonella being present in a wide variety of foods, although generally at lesser numbers $(14,15)$.

Therefore, the capacity of development as well as the continued existence of bacteria must be monitored not only to notice the microbiological quality but also to evaluate the consumer welfare of such ready to eat food products (16). However, the rapid and accurate identification of foodborne pathogenic bacteria in food is important both for quality assurance and to detect pathogens within the food supply (17). Along these lines, current study focused on the presumptive detection of some common food borne pathogens among the ready to eat food samples.

\section{MATERIALS AND METHODS}

Sampling and sample collection The microbiological analysis of 10 ready to eat food items was categorized into two groups, of which five samples were fried types (fried chicken, fish fillet, shrimp fry, French fries, potato chop) and the rest five were sweet items (yogurt, pudding, ice cream, mango drink, lemon drink. These samples were collected from various vendor food shops of Dhaka city, 
Bangladesh within the period of January, 2017 to March, 2017. All the samples were transported to the laboratory instantly after collection in sterile plastic bags and kept them in ice box at $4{ }^{\circ} \mathrm{C}$ according to the method suggested by American Public Health Association (18).

Sample processing and enrichment of samples. In case of every sample, 10 g sample was weighted and then homogenized in $90 \mathrm{ml}$ normal saline (NS) to make a $100 \mathrm{ml}$ sample suspension for the microbiological examinations. For enrichment purposes, $1 \mathrm{ml}$ of each sample was added to $9 \mathrm{ml}$ of the selenite cysteine broth (SCB) ((Difco Laboratories, Detroit, Mich.) for both Salmonella and Shigella spp. Culture suspensions were incubated for 4 hours at $37{ }^{\circ} \mathrm{C}$ at $100 \mathrm{rpm}(19)$.

Enumeration of total viable bacterial count (TVBC) and total coliform count (TCC). For the enumeration of total viable bacteria and coliforms (especially E. coli and Klebsiella spp.), an aliquot of $0.1 \mathrm{~mL}$ of each suspension was introduced onto the nutrient agar (NA) plates and MacConkey agar plates. After spreading $0.1 \mathrm{ml}$ suspension from the dilution $10^{-3}$, the $\mathrm{NA}$ and MacConkey agar plates were incubated at $37{ }^{\circ} \mathrm{C}$ for 24 hours (19)

Detection of Bacillus spp., Salmonella spp., and Shigella spp._Starch agar plates were used to enumerate the contaminating Bacillus spp. within the examined samples while Salmonella-Shigella (SS) agar was used both for the isolation and enumeration of Salmonella and Shigella spp. After incubation at $37{ }^{0} \mathrm{C}$ for 24 hours, characteristic colonies were noticed and enumerated. Colonies with zone of starch hydrolysis followed by formation of starch iodine complex upon addition of iodine on the plate indicated the presence of Bacillus spp. while the black-centered colony while the black centered colony on Salmonella-Shigella agar was regarded as Salmonella spp. and the colorless colony on the same agar plates were noted as Shigella spp. (20).

Isolation of Staphylococcus spp., Pseudomonas spp. Staphylococcus \& Pseudomonas spp. were isolated from the Mannitol Salt Agar (MSA) \& Pseudomonas agar (PA) individually by spreading $0.1 \mathrm{ml}$ of the diluted samples on these media \& then incubated at $37{ }^{\circ} \mathrm{C}$ for 24 hours (21)

Biochemical tests Identification of the isolates was done by major biochemical tests, for example- Triple Sugar Iron (TSI), Motility Indole Urease (MIU), Methyl-Red (MR), Voges-Proskauer (VP) and Citrate Utilization were performed following the standard methods (22)

\section{RESULTS AND DISCUSSIONS}

Foodborne diseases are the foremost global problem causing considerable morbidity and mortality each year (23). The most frequent known causes of foodborne diseases are pathogenic bacteria. In this study, the goal was to analyze the microbiological quality of RTE food produced by various vendor food shops within Dhaka metropolitan, Bangladesh. Therefore, the current study attempted to check the presence of microorganisms in various ready to eat food items in terms of total viable count as well as in the finding of different pathogenic organisms such as Vibrio spp., Salmonella spp. and Shigella spp.

\section{Isolation and enumeration of microorganisms}

Total Viable Bacterial Count (TVBC). In this study, the total viable bacterial counts ranged from $1 \times 10^{3} \mathrm{cfu} / \mathrm{g}$ to $1.94 \times 10^{6} \mathrm{cfu} / \mathrm{g}$ which were found in ice cream and potato chop respectively (Table 11 ). This finding was quite similar to the study conducted by Oranusi et al. (24). According to FDA guideline, 2013 (25), the acceptable limit is $5 \times 10^{4}-10^{5} \mathrm{cfu} / \mathrm{g}$ in case of total viable bacteria.

E. coli, Klebsiella spp., Salmonella spp. and Shigella spp. count. Among all the ten samples, the highest $E$. coli count was observed as $3.1 \times 10^{4} \mathrm{cfu} / \mathrm{g}$ in fried shrimp whereas the lowest count was $3.8 \times 10^{2}$ $\mathrm{cfu} / \mathrm{g}$ in mango drink (Table 1). In this study, the detection of coliform bacteria, especially E. coli in four
Samples shows the possibility of the presence of fecally contaminated microorganism as also suggested by Adams and Moss (26). but in contrast with Tambekar et al. (27) Salmonella or Shigella species were not identified.

Staphylococcus aureus count. Staphylococcus aureus count was observed within the range from $1.1 \times 10^{2} \mathrm{cfu} / \mathrm{g}-$ $7.5 \times 10^{3} \mathrm{cfu} / \mathrm{g}$ which was found on French fies and fried chicken respectively (Table 1 ). The presence of $S$. aureus in RTE food is an indication of poor hygiene practices. $S$. aureus in RTE food is associated with cross contamination occurring during processing and storage or through the contamination of raw ingredients (28).

Bacillus spp. count. Bacillus spp. count was noticed only in one sample. The count was recorded as $1.0 \times 10^{3}$ $\mathrm{cfu} / \mathrm{g}$ in case of French fries samples. The occurrence of Bacillus spp. in this study is similar as suggested by Rajkowski and Bennett (29) that these bacteria are coupled with the production of toxin; which causes food poisoning. These bacteria are available in dust, soil and raw food and can survives normal cooking as a heat resistant spore. These heat-resistant spores may have survived processing while vegetative cells were destroyed (27).

\section{CONCLUSION}

It is compulsory that foods must be free from contaminations as much as possible. The existence of $E$. coli, S. aureus and Bacillus spp. indicates a potential health risk as these organisms are pathogenic and have been implicated in food borne diseases $(30,31,32)$. Based on the specifications by International Commission for Microbiological Specification for Foods (33), the level of contaminations was within acceptable microbiological limits except for potato chop; this could be attributed to improper processing, poor handling practices and postcross contamination which can create risk to the health of the consumers. Foodborne illness can be barred by good hygiene practices such as the use of Hazard Analysis Critical Control Point (HACCP) application in the chain of food production, processing and storage. Ensuring proper guidance and education to the food handlers/ food vendors on food safety practices and strict control of ready-to-eat foods sold to the busy city inhabitants should be properly monitored by the relevant authorities to avert the epidemics of food borne illness within the Dhaka metropolitan area.

\section{CONFLICT OF INTEREST}

Authors have no conflict of interest.

\section{ACKNOWLEDGEMENT}

I do acknowledge Stamford University Bangladesh for financial and technical support. 
TABLE 1. Isolation and enumeration of microorganisms found from ready to eat food samples

\begin{tabular}{|c|c|c|c|c|c|c|c|}
\hline Sample & $\begin{array}{c}\text { Total Viable } \\
\text { Bacteria }(\mathbf{c f u} / \mathrm{g})\end{array}$ & $\begin{array}{l}\text { S. aureus } \\
(\mathbf{c f u} / \mathrm{g})\end{array}$ & $\underset{(\text { (cfu/g) }}{\text { Escherichia coli }}$ & $\begin{array}{c}\text { Klebsiella } \\
\text { spp. }(\mathbf{c f u} / \mathrm{g})\end{array}$ & $\begin{array}{l}\text { Salmonella } \\
\text { spp. cfu/g) }\end{array}$ & $\begin{array}{l}\text { Shigella spp. } \\
\quad(\mathrm{cfu} / \mathrm{g})\end{array}$ & $\begin{array}{l}\text { Bacillus spp. } \\
\quad(\mathrm{cfu} / \mathrm{g})\end{array}$ \\
\hline Fried Chicken & $1.4 \times 10^{4}$ & $7.5 \times 10^{3}$ & 0 & 0 & 0 & 0 & 0 \\
\hline Fish fillet & $2.5 \times 10^{5}$ & $1.30 \times 10^{2}$ & 0 & 0 & 0 & 0 & 0 \\
\hline Shrimp fry & $5.4 \times 10^{4}$ & $2.2 \times 10^{3}$ & $3.1 \times 10^{4}$ & 0 & 0 & 0 & 0 \\
\hline French Fries & $1.0 \times 10^{5}$ & $1.1 \times 10^{2}$ & $3.8 \times 10^{3}$ & 0 & 0 & 0 & $1.0 \times 10^{3}$ \\
\hline Potato Chop & $1.9 \times 10^{6}$ & $2.6 \times 10^{3}$ & $1.1 \times 10^{4}$ & 0 & 0 & 0 & 0 \\
\hline Yoghurt & $5.0 \times 10^{5}$ & 0 & 0 & 0 & 0 & 0 & 0 \\
\hline Pudding & $3.3 \times 10^{3}$ & 0 & 0 & 0 & 0 & 0 & 0 \\
\hline Ice cream & $1.0 \times 10^{3}$ & $2.0 \times 10^{2}$ & 0 & 0 & 0 & 0 & 0 \\
\hline Mango drink & $4.8 \times 10^{5}$ & $4.0 \times 10^{3}$ & $3.8 \times 10^{2}$ & 0 & 0 & 0 & 0 \\
\hline Lemon drink & $4.4 \times 10^{5}$ & $6.0 \times 10^{3}$ & 0 & 0 & 0 & 0 & 0 \\
\hline
\end{tabular}

TABLE: 2. Biochemical identification of the bacterial isolates from different ready to eat food samples

\begin{tabular}{|c|c|c|c|c|c|c|c|c|c|}
\hline \multirow{2}{*}{$\begin{array}{l}\text { Assumed } \\
\text { Organism }\end{array}$} & \multicolumn{3}{|c|}{ TSI } & \multirow{2}{*}{ 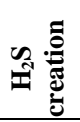 } & \multirow{2}{*}{ 苞苞 } & \multirow{2}{*}{ 害 $\vec{\Xi}$} & \multirow{2}{*}{$\begin{array}{l}\overrightarrow{\underline{w}} \\
\overrightarrow{5}\end{array}$} & \multirow{2}{*}{ 氧 } & \multirow{2}{*}{ 泀 } \\
\hline & slant & Butt & Gas & & & & & & \\
\hline $\begin{array}{c}\text { Staphylococcus } \\
\text { aureus }\end{array}$ & $\mathrm{Y}$ & $\mathrm{Y}$ & - & - & - & + & - & - & - \\
\hline Escherichia coli & Y & Y & + & - & + & + & - & + & + \\
\hline Bacillus spp. & - & - & - & + & - & - & + & + & + \\
\hline
\end{tabular}

TSI = Triple Sugar Iron; Y = Yellow (Acid); R = Red (Alkaline); MR = Methyl red; VP = Voges-Proskauer

\section{REFERENCES}

1. Peck MW, Goodburn KF, Betts RP, Stringer SC. 2008. Assessment of the potential growth and neurotoxin formation by non-proteolytic Clostridium botulinum in shelf-life commercial foods designed to be stored chilled. Trends Food Sci. Technol. 19: 207-216.

2. Food and Environmental Hygiene Department (FEHD). 2001. Microbiological guidelines for Ready-to-eat Food. Food and Environmental Hygiene Department, Queensway, Hong Kong.

3. Food Safety Authority of Ireland (FSAI). 2001. Guidelines for the interpretation of results for Microbiological Analysis of some Ready-to-eat food samples at the Point of Sale. Food Safety Authority of Ireland. 3: 112.

4. Powers T, Barrows C. 1999. Introduction to Management in the Hospitality Industry. 6th Ed. John Wiley and Sons, Inc, New York.

5. Ansari CB. 2015. Bacteriological examination of ready-to-eat foods (RTE) products of Tehran province, Iran. Adv. Food Sci. Technol. 3 (7): 328-331.

6. Gilbreth SE, Call JE, Wallace FM, Scott VN, Chen Y, Luchansky JB. 2005. Relatedness of Listeria monocytogenes isolates recovered from selected ready-to-eat foods and listeriosis patients in the United States. Appl. Environ. Microbiol. 71: 8115-8122.

7. Gibbons IS, Adesiyun A, Seepersadsingh N, Rahaman S. 2006. Investigation for possible source(s) of contamination of ready-to-eat meat products with Listeria spp. and other pathogens in a meat processing plant in Trinidad. Food Microbiol. 23: 359-366.

8. Mead PS, Slutsker L, Dietz V, McCaig LF, Bresee JS, Shapiro C. 2009. Food-related illness and death in the United States. Emerg. Infect. Dis. 5: 607-625.

9. Nguz K. 2007. Assessing food safety system in sub-Saharan countries: An overview of key issues. Food Control. 18: 131-134.

10. Angelidis AS, Chronis EN, Papageorgiou DK, Kazakis II, Arsenoglou KC, Stathopoulos GA. 2006. Non-lactic acid contaminating flora in ready-to-eat foods: A potential food-quality index. Food Microbiol. 23: 95-100.

11. Colombari V, Mayer MD, Laicini ZM, Mamizuka E, Franco BD, Destro MT. 2007. Foodborne outbreak caused by Staphylococcus aureus: Phenotypic and genotypic characterization of strains of food and human sources. J. Food Protect. 70: 489-493.

12. Von HA, Makhoane, FM. 2006. Improving street food vending in South Africa: Achievements and lessons learned. Intl. J. Food Microbiol. 111: 89-92.

13. de Sousa GB, Tamagnini LM, Olmos PD, Gonzalez RD. 2002. Microbial enumeration in ready-to-eat foods and their relationship to good manufacturing practice. J. Food Saf. 22: 27-38.

14. Emberland KE, Nygard K, Heier BT, Aavitsland P, Lassen J, Stavnes TL, et al. 2006. Outbreak of Salmonella Kedougou in Norway associated with salami. Euro. Surveill. 1 (7): E060706.3. 
15. Swaminathan B, Gerner-Smidt P. 2007. The epidemiology of human listeriosis. Microbes Infect. 9: 1236-1243.

16. Tavoschi L, Severi E, Niskanen T, Boelaert F, Rizzi V, Liebana E. 2015. Food-borne diseases associated with frozen berries consumption: a historical perspective, European Union, 1983 to 2013. Euro. Surveille. 20 (29): 21193.

17. Hyun- Joong K, Si- Hong P, Tae- Ho L. 2008. Microarray detection of food-borne pathogens using specific probes prepared by comparative genomics. Biosensors Bioelectron. 24: 238- 246.

18. American Public Health Association (AHPA). 1998. Standard methods for the examination of water and wastewater. American Public Health Association, Washington, D.C.

19. Marjan S, Das KK, Munshi SK, Noor R. 2014. Drug-resistant bacterial pathogens in milk and some milk products. Nutri. Food Sci. 44 (3): 241248.

20. Acharjee M, Rahman F, Jahan F, Noor R. 2013. Bacterial proliferation in municipal water supplied in mirpur locality of Dhaka city, Bangladesh. Clean - Soil, Air, Water. 42 (4): 434-441.

21. Rahman F, Noor R. 2012. Prevalence of pathogenic bacteria in common salad vegetables of Dhaka Metropolis. Bangladesh Journal of Botany. 41 (2): $159-162$.

22. Alfrad EB. 2007. Bensons Microbiological Applications. Mcgraw-Hill Book Company, New York

23. Hanson LA, Zahn EA, Wild SR, Döpfer D, Scott J, Stein S. 2012. Estimating global mortality from potentially foodborne diseases: An analysis using vital registration data. Population Health Metrics. 10: 5.
24. Oranusi, SU, Oguoma OI, Agusi E. 2013. Microbiological quality assessment of foods sold in student's cafeterias. Global Res. J. Microbiol. 3 (1): $1-7$.

25. Food and Drug Administration (FDA). 2013. Revised guidelines for the assessment of microbiological quality of processed foods.

26. Adams MR, Moss MO. 2008. Bacterial agents of foodborne illness. In Food Microbiology, $3^{\text {rd }}$ ed. The Royal Society of Chemistry, Cambridge, United Kingdom.

27. Tambekar DH, Jaiswal V, Dhanorkar D, Gulhane P, Dudhane M. 2008. Identification of microbiological hazards and safety of ready-to-eat food vended streets of Amravati City, India. J. Appl. Biosci. 7: 195-201.

28. Akindele PO, Ibrahim KA. 2016. Microbiological analysis of ready-to-eatfoods obtained from bukaterian within the Ekiti State University and environment, Ado-Ekiti, Nigeria. J. Adv. Microbiol. 1 (2): 1-8.

29. Rajkowski KT, Bennett RW. 2003. International Handbook of foodborne Pathogens. Marcel Dekker, Inc. New York.

30. Granum PE. 2005. Microbiology and Molecular Biology. Caister Academic Press, Great Britain.

31. Wagner AB. 2009. Epidemiology of food poisoning outbreaks in Singapore, 2001- 2005. Epidemiol. News Bulletin J. Microbiol. 31: 68-72.

32. Canadian Food Inspection Agency (CFIA). 2009., Salmonella Food Safety Facts, Preventing foodborne illness.

33. International Commission on Microbiological Specifications for Foods (ICMSF). 1996. Microorganisms in Foods 5: Microbiological Specifications of Pathogens. 